\title{
Tumor microenvironment controls the rate of cancer progression and metastasis
}

\author{
Raghu Kalluri \\ From 16th International Charles Heidelberger Symposium on Cancer Research \\ Coimbra, Portugal. 26-28 September 2010
}

Tumors are unorganized organs that contain many different cell types that communicate with cancer cells (Kalluri NRC 2006). The central goal of our laboratory is to evaluate the role of these non-cancer cells in cancer progression and metastasis. Cancer progression significantly depends on the influence of many different host cells. Whether such host responses are recruited to control cancer progression or further aid in tumor growth (or both) is still unclear. This lecture will highlight the role of extra-cellular matrix, angiogenesis, and mesenchymal cells in cancer progression and metastasis, and discuss treatment strategies.

Published: 24 September 2010

doi:

Cite this article as: Kalluri: Tumor microenvironment controls the rate of cancer progression and metastasis. BMC Proceedings 2010 4(Suppl 2):011.

Correspondence: rkalluri@bidmc.harvard.edu

Division of Matrix Biology, Beth Israel Deaconess Medical Center, Harvard Medical School, Boston, MA 02215
Submit your next manuscript to BioMed Central and take full advantage of:

- Convenient online submission

- Thorough peer review

- No space constraints or color figure charges

- Immediate publication on acceptance

- Inclusion in PubMed, CAS, Scopus and Google Scholar

- Research which is freely available for redistribution

Submit your manuscript at www.biomedcentral.com/submit 